\title{
Properties of atmospheric humic-like substances - water system
}

\author{
I. Salma, R. Ocskay, and G. G. Láng \\ Eötvös University, Institute of Chemistry, Budapest, Hungary \\ Received: 7 November 2007 - Published in Atmos. Chem. Phys. Discuss.: 5 February 2008 \\ Revised: 8 April 2008 - Accepted: 9 April 2008 - Published: 24 April 2008
}

\begin{abstract}
Urban-type $\mathrm{PM}_{2.5}$-fraction aerosol samples were collected and samples of pure atmospheric humic-like substances (HULIS) were isolated from them. Atmospheric concentrations of organic carbon (OC), water soluble organic carbon (WSOC) and HULIS were determined, and UV/Vis spectroscopic properties, solubility and conductivity of HULIS in aqueous samples were investigated. Atmospheric concentrations of OC and WSOC were 8.5 and $4.6 \mu \mathrm{g} \mathrm{m}^{-3}$, respectively. Hydrophilic WSOC accounted for $39 \%$ of WSOC, carbon in HULIS made up $47 \%$ of WSOC, and $14 \%$ of WSOC was retained on the separation column by irreversible adsorption. Overall average molecular mass and aromatic carbon abundance of HULIS were estimated from molar absorptivity to be $556 \mathrm{Da}$ and $12 \%$, respectively. Both results are substantially smaller than for standard reference fulvic acids, which imply different mechanisms for the formation processes of atmospheric HULIS and aquatic or terrestrial humic matter. HULIS were found to be water soluble as ionic unimers with a saturation concentration of $2-3 \mathrm{~g}^{-1}$. Their solubility increased again with total HULIS concentration being above approximately $4 \mathrm{gl}^{-1}$, which was most likely explained by the formation of HULIS aggregates. Solubility increased linearly from approximately 5 up to $20 \mathrm{~g}^{-1}$ of dissolved HULIS concentration. The ionic dissolution was confirmed by electrochemical conductivity in the investigated concentration interval. Limiting molar conductivity was extrapolated and this was utilized to determine the apparent dissociation degree of HULIS for different concentrations. The dissociation degree was further applied to derive the concentration dependence of the van't Hoff factor of HULIS. The van't Hoff factor decreased monotonically with HULIS concentration; the decrease was substantial for dilute solutions and the relationship became weak for rather concentrated solutions.
\end{abstract}

Correspondence to: I. Salma

(salma@chem.elte.hu)

\section{Introduction}

The effects of atmospheric aerosols on climate change may be very substantial but are poorly quantified at present. There is conclusive evidence that both inorganic salts and organic compounds, in particular the water-soluble components in fine-sized atmospheric aerosol particles play an important role. The effects of inorganic salts were studied in detail and are well documented. The influence of organic compounds is far less understood and largely uncertain, particularly in relation to that of the dominant inorganic aerosol components (Fuzzi et al., 2006; McFiggans et al., 2006). This is definitely caused by the large number (up to several hundreds or a thousand) and the structural complexity of the carbonaceous compounds involved, and by the difficulties associated with the collection, separation and analytical methods available for them. Wide ranging identification and quantification of the organic molecules contained in the aerosol particles is very difficult, and the methods most proven typically resolve at most only $10-20 \%$ of the organic mass into specific compounds (Rogge et al., 1993; Saxena and Hildemann, 1996; Mazurek et al., 1997; Puxbaum et al., 2000). Instead of the characterisation at the molecular level, the carbonaceous matter is frequently divided into some generic or operationally defined groups that are characterized and dealt with in models. Organic carbon (OC) and elemental carbon (EC) are the main groups of fine-sized carbonaceous matter. Organic carbon is frequently divided into two major physicochemical fractions, i.e., water-soluble and water-insoluble carbon (WSOC and WInsOC, respectively). The separation of each main fraction into major chemical classes of compounds and surrogate molecules is still feasible and this was shown to be advantageous for characterizing the properties of bulk organic matter and chemical fractions (e.g., Decesari et al., 2000; Mayol-Bracero et al., 2002). The main disadvantage of this approach is that it suffers from methodological, conceptual and principled limits.

Published by Copernicus Publications on behalf of the European Geosciences Union. 
One of the most important classes of water-soluble organic compounds is atmospheric HUmic-LIke Substances (HULIS) (Havers et al., 1998; Zappoli et al., 1999; Gelencsér et al., 2000; Krivácsy et al., 2000; Decesari et al., 2000; Fuzzi et al., 2001; Kiss et al., 2002; Decesari et al., 2006). They are present ubiquitously in the troposphere and make up a major fraction of continental fine-sized water-soluble organic compounds (Salma et al., 2007, and references therein). HULIS are regarded as polymeric material with strong polar, poly-acidic, and chromophoric properties, and which are comprised primarily of a complex multi-component mixture of aromatic compounds that have aliphatic chains with carboxyl, hydroxyl, methoxyl or carbonyl terminal groups (Decesari et al., 2000; Krivácsy et al., 2000; Kiss et al., 2002; Graham et al., 2002; Cappiello et al., 2003; Gelencsér, 2004; Tagliavini et al., 2005; Samburova et al., 2007). They exhibit strong surface activity (Facchini et al., 1999, 2000; Decesari et al., 2001; Kiss et al., 2002; Salma et al., 2006; Varga et al., 2007; Taraniuk et al., 2007; Wex et al., 2007) by which they influence the properties of the gas-liquid interface of droplets in the air. HULIS could have amphiphilic properties as well which can cause aggregation above a critical concentration level. In addition, HULIS are optically active (coloured) and can interact directly with the sunlight (Dinar et al., 2008). The exact chemical composition and physicochemical properties of HULIS and their formation mechanisms are being studied increasingly and intensively (Graber and Rudich, 2006, and references therein). Nevertheless, our knowledge on its water solubility, dissociation and molecular mass is still deficient despite being governing variables (together with the surface activity and osmolality) in many important atmospheric processes, like the growth of aerosol particles with relative humidity and the activation of cloud droplets (Fuzzi et al., 2006; Koehler et al., 2006; McFiggans et al., 2006; Dinar et al., 2007; Wex et al., 2007). For instance, the van't Hoff factor, which represents the average number of ions into which a molecule dissociates when dissolved, was classified as one of the most significant sources of uncertainty in the Köhler model involving aggregate organics (Asa-Awuku et al., 2007; Ziese et al., 2008). Improved knowledge on these properties could lead to a better understanding of and quantifying the role HULIS play in the atmospheric and climatic systems, as well as provides us with insights into the main source processes and pathways of this mixture.

Pure HULIS samples were isolated from urban-type atmospheric aerosol samples and the HULIS-water system was investigated by physicochemical and analytical methods in order to decide whether HULIS form aggregates (micelles) in aqueous solutions with atmospherically relevant concentrations or not, to study their solubility, to determine their dissociation degree and van't Hoff factor for different concentrations, to estimate their average molecular mass and to derive the abundance of aromatic carbon within HULIS. The main objectives of the present paper are to report and discuss the findings achieved, to interpret the results and to formulate some consequences for air chemistry and cloud physics.

\section{Experimental}

\subsection{Samples and sample treatment}

The aerosol samples were collected in central Budapest from 2 till 9 May, and from 17 till 24 July 2006 as a continuation of our urban carbonaceous aerosol research (Salma et al., 2004, 2006, and 2007). The sampling site was located in a small park at Széna Square (latitude $47^{\circ} 37.4^{\prime} \mathrm{N}$, longitude $19^{\circ} 01.7^{\prime} \mathrm{E}$, altitude $114 \mathrm{~m}$ above the mean sea level). The site is heavily influenced by vehicular traffic. During the two sampling periods, the average micrometeorological conditions were rather similar, and the air quality parameters were also close to each other. For instance, the daily-mean $\mathrm{PM}_{10}$ mass concentration varied between 25 and $46 \mu \mathrm{g} \mathrm{m}^{-3}$ with a median of $35 \mu \mathrm{g} \mathrm{m}^{-3}$ for the spring period, and ranged from 27 to $54 \mu \mathrm{g} \mathrm{m}^{-3}$ with a median of $35 \mu \mathrm{g} \mathrm{m}^{-3}$ for the summer period. The mean ozone concentration for daylight time was $57 \mu \mathrm{g} \mathrm{m}^{-3}$ with an hourly maximum value of $148 \mu \mathrm{g} \mathrm{m}^{-3}$ for the spring period, and the mean was $70 \mu \mathrm{g} \mathrm{m}^{-3}$ with an hourly maximum value of $156 \mu \mathrm{g} \mathrm{m}^{-3}$ for the summer period. As a consequence, the formation processes of HULIS for both sampling periods were regarded to be similar, and the possible deviations in the properties of the HULIS samples were expected to be within the experimental uncertainty. The aerosol samples were taken by a DHA-80 high volume aerosol sampler equipped with a $\mathrm{PM}_{2.5}$ pre-separator (both Digitel Elektronik, Switzerland), and operated at an air flow rate of $5001 \mathrm{~min}^{-1}$ for one week. The sampler was placed in a regular station of the municipal air quality monitoring network with the inlet at a height of $4 \mathrm{~m}$ above the ground. Whatman QM-A quartz fiber filters were used as the collection substrate. The filters were pre-baked at $450^{\circ} \mathrm{C}$ for at least 8 hours before sampling to remove the possible organic contaminants. The exposed area of the filters was $154 \mathrm{~cm}^{2}$. The samples were kept in a freezer until further treatment or analysis.

The main section of the aerosol filters was utilized for isolation of pure HULIS. The filters were cut into pieces and extraction was carried out with the high-purity reagent Milli-Q water (approximately $1 \mathrm{ml}$ water per $1 \mathrm{~cm}^{2}$ filter) for $36 \mathrm{~h}$. Removal of the WSOC from the filters was checked by repeated extraction of a selected filter section and was found to be quantitative. The water extracts were filtered through a $0.22 \mu \mathrm{m}$ syringe PVDF membrane filter (Millipore, USA) to remove the filter debris and suspended insoluble particles. The pure HULIS were isolated from the solution by a modified one-step solid-phase extraction (SPE) method (Varga et al., 2001; Kiss et al., 2002) based on the hydrophilic/lipophilic character of the non-dissociated organic compounds. The $\mathrm{pH}$ of the filtrates was adjusted to 2 with 
$\mathrm{HCl}$, and HULIS were separated by pre-conditioned SPE columns (Oasis HLB, Waters, USA). Organic compounds with acidic functional groups that are protonated at $\mathrm{pH}=2.0$ (including aromatic acids, phenols, organic nitrates, aliphatic mono- or dicarboxylic acids with more than 3-4C atoms) are retained by the column, while the inorganic species and the organic compounds that are very hydrophilic due to the presence of strong polar functional groups (including saccharides, amines, aliphatic mono- or dicarboxylic acids with less than 4-5 C atoms) pass into the effluent (Sullivan and Weber, 2006a, 2006b). The isolation method was optimized to separate the fraction that exhibits the key spectral properties of HULIS, i.e. more than $90 \%$ of the fluorescence activity and $70 \%$ of the UV activity for humic and fulvic acids (Varga et al., 2001). The exposed column was rinsed with water to remove the remaining inorganic species and dried with nitrogen. The retained organics were eluted with methanol, and the eluents were evaporated to dryness with a gentle nitrogen stream. The resulting dark yellow/brown pulp is regarded to be consisted of pure HULIS. The samples were kept in a refrigerator until further dissolution.

The water solubility of pure HULIS was investigated by adding $600 \mu \mathrm{l}$ water to one of the HULIS samples with a mass of approximately $18 \mathrm{mg}$. The aqueous sample was put into ultrasonic bath for $15 \mathrm{~min}$, after which it was allowed to stand in an ultra-thermostat at a constant temperature of $20^{\circ} \mathrm{C}$ for a day. The $\mathrm{pH}$ of the aqueous sample was measured by a glass microelectrode. An aliquot with a volume of $160 \mu \mathrm{l}$ was taken out from the aqueous sample, this was filtered through a syringe PVDF membrane filter with a pore size of $0.22 \mu \mathrm{m}$ and a dead volume of $10 \mu \mathrm{l}$ (Millipore, USA). The dissolved OC concentration was measured by a TOC analyser (see Sect. 2.2). The remaining volume of the aqueous sample was diluted further with water; the sample preparation described above was repeated, and the $\mathrm{pH}$ and dissolved OC concentration were determined. A series of 13 HULIS aqueous samples with consecutive dilution factors of 1.0, 1.2, $1.2,1.2,1.2,1.2,1.4,1.5,2.0,1.5,1.6,1.7$ and 1.6 was prepared and measured in this way.

The conductivity of HULIS aqueous samples was investigated by adding $600 \mu \mathrm{l}$ water to one of the pure HULIS samples with a mass of approximately $6 \mathrm{mg}$. The aqueous sample was put into ultrasonic bath for $15 \mathrm{~min}$, after which it was allowed to stand in an ultra-thermostat at a temperature of $20^{\circ} \mathrm{C}$ for one day. The $\mathrm{pH}$ of the aqueous sample was measured by a glass micro-electrode, and its conductivity was determined by using electrochemical impedance spectroscopy (EIS, see Sect. 2.2). After the EIS measurement, an aliquot of the HULIS aqueous sample was taken out, it was filtered through the syringe PVDF membrane filter with a dead volume of $10 \mu \mathrm{l}$, and the dissolved OC concentration in the filtrate was measured by the TOC analyzer. The remaining volume of the aqueous sample was diluted further with water, and the sample preparation and measurements were accomplished as described above. A series of eight HULIS aqueous samples with consecutive dilution factors of 1.0, 1.9, 2.1, 2.0, 2.6, 1.6, 1.9 and 10 was prepared and measured in this way.

Standard Suwannee River Fulvic Acid (SRFA, code 2S101F) was obtained from the International Humics Substances Society (IHSS, based in St. Paul, USA) for comparative purposes. Its detailed chemical characterization can be found at the URL http://www.ihss.gatech.edu/. The SRFA was chosen since several previous studies referred to it as representative of atmospheric HULIS. The SRFA was dissolved in Milli-Q water, and the solutions were used for further experiments without any sample treatment.

\subsection{Measuring methods and data treatment}

The organic carbon content of the aerosol samples was determined directly from punches with an area of $1 \mathrm{~cm}^{2}$ of the original quartz filters by the thermal-optical transmission (TOT) method (Birch and Carry, 1996) using a Sunset Lab (USA) instrument at Ghent University, Belgium. The NIOSH2 temperature program suggested for heavily loaded filters and large EC abundances was used in the analysis (Schauer et al., 2003).

Concentration of OC for the filtered aerosol water extracts, effluents of the SPE columns and for HULIS solutions were measured by a Multi N/C 2100S total carbon analyzer (Analytik Jena, Germany). The OC was derived in two steps as the difference between total carbon and inorganic carbon. The injection volume was $500 \mu \mathrm{l}$ for both steps, and three replicate injections were carried out. The measured concentration levels were at least two orders above the detection limit for OC (which was $50 \mathrm{ppb}$ ), and the relative uncertainty of the mean OC calculated from the three individual results was less than $2 \%$.

The UV/Vis spectra of the aqueous HULIS and SRFA solutions were recorded in the range of 190 to $500 \mathrm{~nm}$ with a Lambda 12 spectrophotometer (Perkin-Elmer, USA) in a quartz cuvette with a path length of $1 \mathrm{~cm}$ using Milli-Q water as the blank sample.

The conductivity of HULIS aqueous samples was determined using electrochemical impedance spectroscopy. Its major advantage is that the method measures the variation of the impedance with frequency, which allows a high-precision and reliable determination of the solution resistance (Láng et al., 2001; Hantz et al., 2004). A cylindrical electrochemical measurement cell with an internal diameter of $4 \mathrm{~mm}$ and effective volume of $500 \mu \mathrm{l}$ was made of glass and it was equipped with Pt working electrodes. The cell constant was derived with a $\mathrm{KCl}$ solution with a concentration of $0.02 \mathrm{~mol}^{-1}$. All measurements were performed at a constant temperature of $20^{\circ} \mathrm{C}$ applying a sinusoidal perturbing signal with an amplitude of 5 or $10 \mathrm{mV}$ over a frequency range of $1 \mathrm{~Hz}$ to $13 \mathrm{kHz}$. Each aqueous sample was measured at least three times, and the resistance of the solution was calculated by extrapolating the real part of the complex 


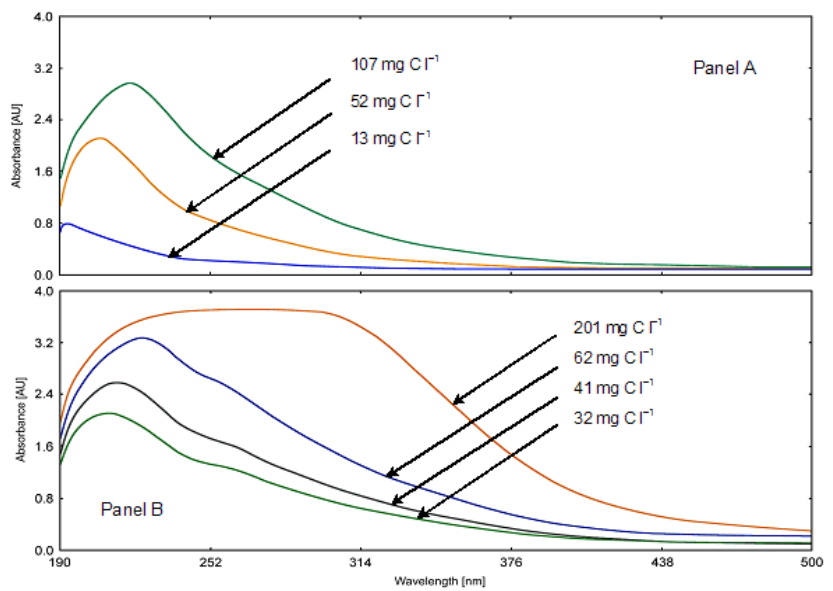

Fig. 1. UV/Vis spectra of atmospheric HULIS (Panel A) and standard SRFA (Panel B) aqueous solutions with different concentrations.

impedance to the high frequency limit. The corresponding results were averaged, and the conductivity was finally derived from the average ohmic resistance and cell constant. The relative uncertainty of the determinations is estimated to be less than $2 \%$.

\section{Results}

3.1 Atmospheric concentrations and partitioning of carbonaceous fractions

The atmospheric concentrations of $\mathrm{OC}$ and $\mathrm{EC}$ in the $\mathrm{PM}_{2.5^{-}}$ fraction aerosol were 9.0 and $3.5 \mu \mathrm{g} \mathrm{m}^{-3}$, respectively for the spring period, and they were 7.9 and $3.5 \mu \mathrm{g} \mathrm{m}^{-3}$, respectively for the summer period. Water-soluble organic carbon accounted for $58 \%$ of the OC; the rest (42\%) was regarded to be WInsOC. The atmospheric concentrations of HULIS for the spring and summer periods were 4.7 and $3.8 \mu \mathrm{g} \mathrm{m}^{-3}$, respectively using the organic matter-to-organic carbon mass conversion factor of 1.81 derived especially for HULIS (Salma et al., 2007). The contribution of HULIS carbon (HULIS-C) to OC was $28 \%$ for both seasons. Most values and ratios agree reasonably well with the data obtained earlier for central Budapest for spring periods but the WSOC and HULIS concentrations are larger than the values reported previously (Salma et al., 2004, 2007). This can most likely be explained by the fact that the sampling artefacts for carbonaceous species were not taken into account in the present work. The sampling artefacts for organic aerosol constituents were investigated by tandem filter subtraction method in a previous study in Budapest. A significant positive (adsorptive) bias for HULIS was observed and its occurrence was explained (Salma et al., 2007). During the present collection periods, the meteorological conditions favoured photochem- ical reactions and formation of semi-volatile organic species and, consequently, enhanced the extent of the sampling artefacts. Aerosol samples collected by high-volume devices and for relatively long times are especially susceptible to sampling artefacts.

The concentrations of TOC in the filtrated aerosol water extract samples, SPE effluents, and SPE eluents allowed us to determine the WSOC partitioning between the separated chemical fractions for a real aerosol. It is noted here that the isolation procedure described in Sect. 2.1 was extended by one more step for the purpose of this particular experiment, i.e., the SPE column activated with methanol was dried with nitrogen in order to remove the methanol residues. It was observed that $39 \%$ of the total WSOC passed through the SPE column with the effluent (this chemical fraction is called hydrophilic WSOC), and the rest was adsorbed on the stationary phase. Elution from the column yielded $47 \%$ of the total WSOC, which implies that $14 \%$ was retained on the column by irreversible adsorption. It will be shown in Sect. 3.2 that the absorbance at a wavelength of $280 \mathrm{~nm}$ can be regarded as one of the most appropriate optical characteristics for HULIS, and, therefore, the partitioning of HULIS was determined by this absorbance as well. The absorbance for eluent represented $68 \%$ of the absorbance of the filtered aerosol water extract sample (which agrees well with the optimized data of $70 \%$, see Sect. 2.1), while the retained organic compounds accounted for $15 \%$ of the absorbance of the filtered aqueous extract in agreement with the data derived for the WSOC. The share of the irreversible sorption is comparable to that of approximately $25 \%$ and of $10-15 \%$ obtained by other (independent) isolation methods (Limbeck et al., 2005; Sulliwan and Weber, 2006a, respectively).

The relative amounts of WSOC in the hydrophilic and irreversibly bound chemical fractions were linked to their anthropogenic and biogenic origin (Sullivan and Weber, 2006b). Following the assumptions of these authors, biogenic emissions in central Budapest would account for at least $15 \%$ of the WSOC. The situation is likely much more complex because 1) biogenic material dominates the WInsOC fraction (Szidat et al., 2004; Puxbaum and TenzeKunit, 2003), which made up $42 \%$ of OC for the present samples, 2) HULIS can also be formed from biogenic precursors (e.g., Limbeck et al., 2003; Kalberer et al., 2004; Baltensperger et al., 2005), and 3) some organics of biogenic origin can show up in the hydrophilic WSOC chemical fraction as well. Further investigations utilizing molecular markers are definitely needed for estimating the real contribution of biogenic sources.

\subsection{Molar absorptivity}

Selected UV/Vis absorption spectra of HULIS and standard SRFA aqueous solutions are shown in Fig. 1 as examples. It is seen that the spectra of HULIS and diluted SRFA solutions are similar. Nevertheless, the spectra are actually fea- 
Table 1. Molar absorptivity $(\varepsilon)$ determined at wavelengths of 254 and $280 \mathrm{~nm}$, molecular mass $(M)$ in Da and percentage of aromatic carbon content $(A r)$ derived for atmospheric HULIS and standard SRFA samples. Data affected by absorbance overloading were put in parenthesis.

\begin{tabular}{lllllll}
\hline $\begin{array}{l}\text { OC } \\
{\left[\mathrm{mg} \mathrm{C}^{-1}\right]}\end{array}$ & $\begin{array}{l}\varepsilon(254 \mathrm{~nm}) \\
{\left[1(\mathrm{~mol} \mathrm{C})^{-1} \mathrm{~cm}^{-1}\right]}\end{array}$ & $\begin{array}{l}\varepsilon(280 \mathrm{~nm}) \\
{\left[1(\mathrm{~mol} \mathrm{C})^{-1} \mathrm{~cm}^{-1}\right]}\end{array}$ & $\begin{array}{l}\text { Molecular } \\
\text { mass }^{\mathrm{a}}\end{array}$ & $\begin{array}{l}\text { Molecular } \\
\text { mass }\end{array}$ & $\begin{array}{l}\text { Aromaticity } \\
{[\%]}\end{array}$ & $\begin{array}{l}\text { Aromaticity }^{\mathrm{c}} \\
{[\%]}\end{array}$ \\
\hline HULIS & & & & & & \\
13 & 233 & 173 & 763 & 432 & 15 & 13 \\
52 & 210 & 144 & 725 & 414 & 14 & 11 \\
107 & 166 & 114 & 686 & 380 & 12 & 10 \\
136 & 156 & 108 & 677 & 373 & 12 & 9 \\
SRFA & & & & & & \\
32 & 500 & 378 & 1037 & 637 & 26 & 25 \\
41 & 505 & 380 & 1040 & 640 & 26 & 25 \\
62 & 494 & 374 & 1032 & 632 & 25 & 24 \\
201 & $(217)$ & $(218)$ & $(824)$ & $(420)$ & $(18)$ & $(15)$ \\
\hline
\end{tabular}

a Chin et al. (1994): $M=534+1.33 \cdot \varepsilon, A r=6.74+0.05 \cdot \varepsilon$, at $280 \mathrm{~nm}$.

b Schäfer et al. (2002): $M=253+92.1 \cdot \varepsilon$, at $254 \mathrm{~nm}$.

${ }^{\mathrm{c}}$ Peuravuori and Pihlaja (1997): $A r=3.001+0.057 \cdot \varepsilon$, at $280 \mathrm{~nm}$.

tureless, and they do not really give detailed information on the chemical structure of the molecules. The maximum of the absorbance was reached at a wavelength of around 220 $240 \mathrm{~nm}$, depending on the solution concentration. The absorbance decreased monotonically from the maximum with the wavelength for diluted solutions, which is typical for double-bounded and aromatic chemical structures. A shoulder appeared at around $260 \mathrm{~nm}$, which was more pronounced for SRFA than for HULIS. The spectra of more concentrated SRFA solutions exhibited a plateau extending from approximately 230 up to $360 \mathrm{~nm}$. This was the result of absorbance overloading. There was no plateau for the HULIS because its solutions were much more diluted than for the SRFA. The absorbance at a wavelength of $280 \mathrm{~nm}$ was chosen as one of the most useful optical properties because the $\pi-\pi^{*}$ electron transition for aromatic components, like phenolic derivatives, benzoic acids, polyenes and polycyclic aromatic hydrocarbons, which are regarded to be the precursors or structural subunits of humic substances, occurs in the range of 270 $280 \mathrm{~nm}$ (Traina, 1990). The absorbance at a wavelength of $254 \mathrm{~nm}$ was also evaluated for comparative purposes since some studies dealt with absorbance at this value (Schäfer et al., 2002; Dinar et al., 2006), and since it is located closer to the maximal absorbance than the wavelength of $280 \mathrm{~nm}$.

Molar absorptivity $(\varepsilon)$ defined as the absorbance per one mole of $\mathrm{C}$ was calculated for HULIS and SRFA solutions, and they were summarized in Table 1 . The molar absorptivity for SRFA seemed to be more or less constant for the diluted solutions, and it decreased with OC for the more concentrated solutions. Representative molar absorptivity for the SRFA was obtained by averaging the data for the diluted solutions which yielded 500 and $3781(\mathrm{~mol} \mathrm{C})^{-1} \mathrm{~cm}^{-1}$ for the wavelengths of 254 and $280 \mathrm{~nm}$, respectively. The molar absorptivity for HULIS decreased monotonically with OC in the concentration range examined. The representative molar absorptivities for the SRFA agree well with the data of $\sim 4501(\mathrm{~mol} \mathrm{C})^{-1} \mathrm{~cm}^{-1}$ measured for the IHSS fulvic acid with a concentration of $100 \mathrm{mg} \mathrm{Cl}^{-1}$ (Schäfer et al., 2002), and they are comparable to the molar absorptivities of 416 and $3061(\mathrm{~mol} \mathrm{C})^{-1} \mathrm{~cm}^{-1}$ at the wavelengths of 254 and $280 \mathrm{~nm}$, respectively obtained for bulk SRFA (reported without actual OC concentrations, Dinar et al., 2006).

\subsection{Molecular mass and aromatic carbon abundance}

The molar absorptivities derived were utilized to estimate the average relative molecular mass and percentage of the aromatic carbon content (sometimes called aromaticity) of HULIS. The method applied is based on the empirical correlation relationship between molar absorptivity and molecular mass (or size), and between molar absorptivity and aromaticity. The relationships were established for humic substances originating from terrestrial and aquatic sources (e.g., Chin et al., 1994; Peuravuori and Pihlaja, 1997; Tombácz, 1999; Schäfer et al., 2002), and, therefore, their application to the atmospheric HULIS may not be fully justifiable. It is assumed in the method that the relative amount of aromatic moieties (and thus the molar absorptivity) increases with increasing molecular mass of humic substances. A weakness of the method is that the molar absorptivity depends on both the type and concentration of the chromophores in the molecules. Nevertheless, this simple method is still valuable because the type of the chromophores in HULIS and humic substances can be regarded very similar since their relevant optical properties were shown to be almost identical or closely follow each other (Graber and Rudich, 2006, and references therein). The method has not been validated by independent rigorous methods yet but it is thought to 
yield coherent results. The correlation equations utilized are given in Table 1. It is noted that the relationships for the data obtained by Chin et al. (1994) and Schäfer et al. (2002) were actually derived by Dinar et al. (2006). The average molecular mass and aromaticity for the HULIS and SRFA samples are also shown in Table 1. It can be seen that the molecular masses obtained by the correlation of Schäfer et al. (2002) were systematically smaller than those by the equation of Chin et al. (1994). For the representative molar absorptivities of the SRFA solutions (see Sect. 3.2), the average molecular mass ranged from 632 to $1040 \mathrm{Da}$ with an overall average value and standard deviation of $(836 \pm 219)$ $\mathrm{Da}$. The molecular mass of SRFA is expected to be smaller than $1000 \mathrm{Da}$ as determined by various techniques (Brown and Rice, 2000; Leenheer et al., 2001, Kujawinski et al., 2002). The average molecular mass of HULIS varied between 373 and $763 \mathrm{Da}$ with an overall average value and standard deviation of $(556 \pm 170) \mathrm{Da}$. The average molecular mass of HULIS isolated from rural fine-sized aerosol samples by the same SPE method as in the present work was determined by HPLC-MS, and by vapour pressure osmometry, and the values obtained were between 200-300 Da, and between 215-345 Da, respectively (Kiss et al., 2003). Our smallest values (derived by the equation of Schäfer et al., 2002) were the closest to this range, but still somewhat larger. The difference can most likely be explained by the diverse measuring approaches utilized. Samburova et al. (2005) applied size exclusion chromatography - UV spectroscopy, and laser desorption/ionization mass spectrometry to determine the molecular mass distribution of $\mathrm{PM}_{10}$-fraction urban HULIS, and they derived an upper limit of approximately $700 \mathrm{Da}$. Our values are in line with the observations. Dinar et al. (2006) estimated the molecular mass for HULIS isolated from fresh smoke particles, slightly aged wood burning smoke particles, and local photochemical pollution particles to be 610,410 , and $500 \mathrm{Da}$, respectively using the relationship of Schäfer et al. (2002). Our data are in good agreement with the data for the photochemical pollution particles. More importantly, our results prove that the average molecular mass of HULIS for the urban environment is markedly smaller than for aquatic fulvic (or humic) acids. It is one of the few important differences between atmospheric HULIS and humic substances of aquatic and terrestrial origin, and this implies distinct mechanisms for their formation processes. The deviation also implies that the (climate) effects of HULIS cannot be derived by simply adopting the properties that were obtained for standard humic substances originating from aquatic or terrestrial sources.

Aromaticity is a property associated with the extra stability of planar, conjugated systems (with $n$ atoms in the ring) containing the maximum number $(4 n+2)$ of electrons in the $\pi$-bonding molecular orbitals. The presence of aromatic systems influences the reactivity of the functional groups directly attached to the aromatic system. Aromatic carbon abundance can depend on the formation pathways of HULIS, and on the emission sources of its precursors. HULIS in polluted urban environments can be formed as a secondary aerosol from anthropogenic precursors mainly aromatics (Decesari et al., 2002), while for rural or remote regions, formation from dienes (like isoprene) is preferred (Gelencsér, 2004). Hence, comparison of the percentage of the carbon atoms in aromatics can supply useful information on the source regions or formation processes. The correlation equations utilized are given in Table 1 . The average share of the aromatic carbon for the diluted solutions of SRFA was derived to be $25 \%$. Uncertainty of the aromaticity estimated as the relative standard deviation caused by repeated sample preparation and measurements was 10-12\%. The aromatic carbon abundance agrees well with its certified value of $22 \%$ determined by ${ }^{13} \mathrm{C}$-NMR method (IHSS). At the same time, it is substantially larger than the overall mean for HULIS, which was $12 \%$. Dinar et al. (2006) estimated (based on the correlation equation of Peuravuori and Pihlaja, 1997) the aromaticity to be of 20,10 , and $16 \%$ for HULIS isolated from fresh smoke particles, slightly aged wood burning smoke particles, and local photochemical pollution particles, respectively. Our average value for urban HULIS is well comparable with their corresponding data of $16 \%$. The easiest explanation for the difference between the percentage of the aromatic carbon content in the SRFA and HULIS is related to the fact that the relative aromatic content of carbon increases with molecular mass, and the SRFA exhibits larger average molecular mass than HULIS. It is also noted that a small amount of components with a very large molecular mass possibly present in the SRFA standard can have large effect on its aggregate or average properties.

\subsection{Dissolution and colloidal properties}

The relationship between the dissolved HULIS concentration and total (thus dissolved and insoluble) HULIS concentration in the aqueous samples is displayed in Fig. 2. The uncertainty of the concentration data is mainly determined by the micro-chemical operations during the sample preparation. It is seen that the dissolved HULIS concentration increased linearly in the beginning (the correlation coefficient between the four data pairs for the most diluted solutions was $R=0.996$ ) with the total concentration. The slope of the limiting line equals to 1.0 within the experimental uncertainty, which indicates that the isolated HULIS is completely water soluble in small concentrations (as expected). This was caused by classical (ionic) dissolution of unimers. The relationship between them started to level off from a dissolved HULIS concentration of approximately $0.6 \mathrm{~g} \mathrm{l}^{-1}$, and this concentration seemed to reach a more or less constant value of ca. $3 \mathrm{gl}^{-1}$. This behaviour can be explained by the fact that the different components of HULIS gradually reach their solubility limit, after which the aqueous sample becomes saturated with respect to these components, and the enveloping curve results in a levelling off feature. The explanation was confirmed 
by the electrochemical conductivity measurements (cf. the insert of Fig. 2 with Fig. 3) discussed in detail in Sect. 3.5. The presence of some insoluble brown matter within the bulk volume of these aqueous samples and on the walls of the vial could be observed visually. The dissolved concentration increased again rather substantially with total HULIS concentration from approximately $7 \mathrm{gl}^{-1}$, and the increase became linear above a total concentration of $12 \mathrm{gl}^{-1}$. The correlation coefficient for the five data pairs of the most concentrated solutions was $R=1.00$. The linear tendency was maintained up to a dissolved HULIS concentration of approximately $20 \mathrm{gl}^{-1}$. The slope of the line was, however, substantially smaller than 1.0, implying that not all components were dissolved. One of the few possible explanations for this increased solubility can be given by the solubilization of some insoluble components of HULIS by aggregates (e.g., micelles) formed from HULIS. Organic micelle-like aggregates were already observed in solutions of atmospheric particles in small aqueous concentrations (Tabazadeh, 2005). Unfortunately, it was not feasible to detect micelles or critical micelle concentration (CMC) by the techniques utilized in the present investigations. Nevertheless, a CMC between 5 and $10 \mathrm{gl}^{-1}$ was observed for alkali metal humates separated from soil samples (Tombácz, 1999). Their acidic dissociation was found to be of crucial importance in the micelle formation phenomenon, and the effects of the origin of the samples, salting-out, ionic strength and polyvalent cations were also observed (Tombácz, 1999). The solution $\mathrm{pH}$ in the present work increased from 2.2 to 5.5 with dilution, which could also affect the solubility. Taking into consideration this, the reported CMC range corresponds well with our value of $3-4 \mathrm{gl}^{-1}$. Unfortunately, the amount of the spare HULIS aliquot was not satisfactory to identify the micelles directly by the light scattering method.

The phenomenon observed can have consequences on the concentration of HULIS in the solution since the aggregates represent a latent amount. Furthermore, it is known that both aquatic and terrestrial humic matter form stable complexes with and solubilize metal ions. The present study implies that similar processes may occur within cloud droplets containing large amounts of HULIS as a result of their colloidal behaviour.

\subsection{Dissociation degree and van't Hoff factor}

Electrochemical conductivity $(\kappa)$ of pure HULIS solutions as a function of dissolved HULIS-C concentration is displayed in Fig. 3. The character of the curve corresponds to that of the HULIS dissolution curve up to a dissolved HULIS concentration of approximately $2 \mathrm{gl}^{-1}$ shown on the insert of Fig. 2. The first and last three experimental data points were fitted separately by lines in order to obtain the limiting expressions and the intersection point of the lines. The intersection occurred at a HULIS concentration of $0.54 \mathrm{gl}^{-1}$. The value is in good agreement with the declination point at ap-

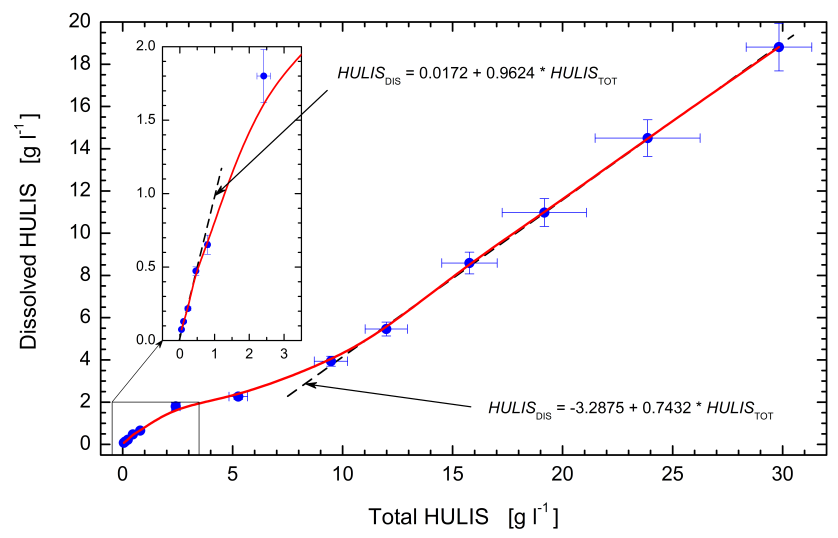

Fig. 2. Dependence of the dissolved HULIS concentration (HULIS $_{\text {DIS }}$ ) on the total HULIS concentration (HULIS $_{\text {TOT }}$ ) in aqueous samples. The range of small concentrations is also displayed in an insert. The connecting curves represent eye guides only. The limiting linear lines (dashed lines) and their analytical expressions are also shown.

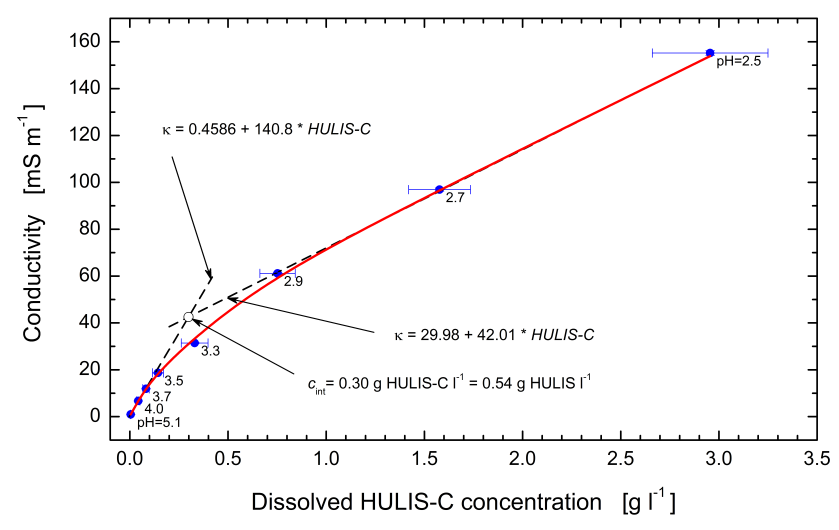

Fig. 3. Electrochemical conductivity $(\kappa)$ of pure HULIS solutions with different dissolved carbon concentration (HULIS-C). The connecting curve represents an eye guide only. The limiting linear lines (dashed lines) and their analytical expression far before and after the intersection-point, the concentration for the intersection-point, and the solution $\mathrm{pH}$ values measured are also indicated.

proximately $0.6 \mathrm{~g} \mathrm{l}^{-1}$ on the dissolution curve. All this supports the mechanism of ionic (classical) dissolution outlined in Sect. 3.4. The presence of some insoluble HULIS could be visually observed in this case again on the walls of the glass vial in the three more concentrated aqueous samples. Molar conductivity data $(\Lambda)$ were calculated as $\Lambda=\kappa / c$, where $c$ is the molar concentration of dissolved HULIS, adopting the smallest average molar mass of $M=373 \mathrm{~g} \mathrm{~mol}^{-1}$ derived in Sect. 3.3 (see the discussion the effect of $M$ on dissociation degree below). Molar conductivity exhibited smaller values in more concentrated solutions, and it increased significantly with decreasing concentration. Molar conductivity in dilute solutions can be expressed by Kohlrausch's empirical 


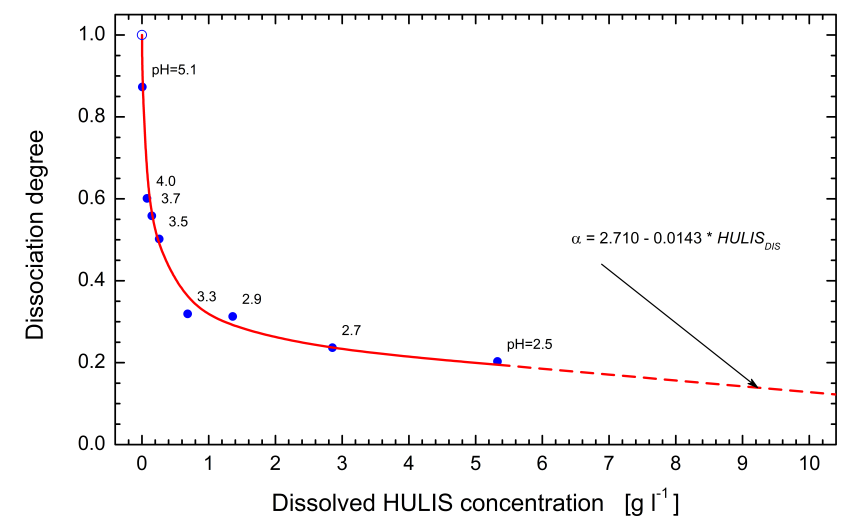

Fig. 4. Dissociation degree $(\alpha)$ of pure HULIS solution with differ-

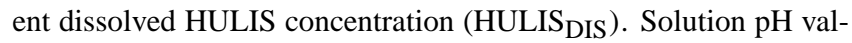
ues measured are also indicated. The connecting curve represents an eye-guide only.

equation: $\Lambda=\Lambda_{0}-k c^{1 / 2}$, where $\Lambda_{0}$ is the molar conductivity at infinite dilution (limiting molar conductivity) and $k$ is a constant. The limiting molar conductivity of HULIS was derived by linear extrapolation to be $\Lambda_{0}=534 \mathrm{~S} \mathrm{~cm}^{2} \mathrm{~mol}^{-1}$. The value is comparable to other ordinary electrolytes in aqueous solution. The limiting molar conductivity for HULIS was utilized further to derive an apparent dissociation degree $(\alpha)$ that can be expressed as $\alpha=\Lambda / \Lambda_{0}$ according to the Arrhenius electrolytic theory of dissociation. It is definitely worth mentioning that both $\Lambda$ and $\Lambda_{0}$ vary to the same extent with the molecular mass of HULIS, and, therefore, the apparent dissociation degree derived as their ratio is independent from the molecular mass actually adopted. This means that the uncertainty related to the molecular mass of HULIS does affect the limiting molar conductivity but, advantageously, it does not influence the value of the dissociation degree. Dependence of the dissociation degree on dissolved HULIS concentration is displayed in Fig. 4. It is seen that HULIS dissociate completely in very dilute solutions (as expected), and that the dissociation degree decreases with concentration. The change is rapid in the beginning, it is slower above a concentration of approximately $1 \mathrm{gl}^{-1}$, and was expressed by a linear line (with a small slope) for concentrations larger than ca. $2.5 \mathrm{~g} \mathrm{l}^{-1}$. The extrapolated line reaches a dissociation degree of zero at a concentration of $19 \mathrm{gl}^{-1}$. The uncertainty of this value can be large since it was extrapolated from a distant concentration interval. Nevertheless, all this implies that in the initial stage of cloud and fog droplet formation on pure HULIS aerosol particles, variation in the dissociation degree of HULIS is modest, but changes substantially in the concentration range relevant for activation of HULIS droplets.

The dissociation degree can be related to the van't Hoff factor $(i)$ by the equation: $i=1+\alpha \cdot(\nu-1)$, where $\nu>1$ is the maximum number of ions the molecule dissociates to when

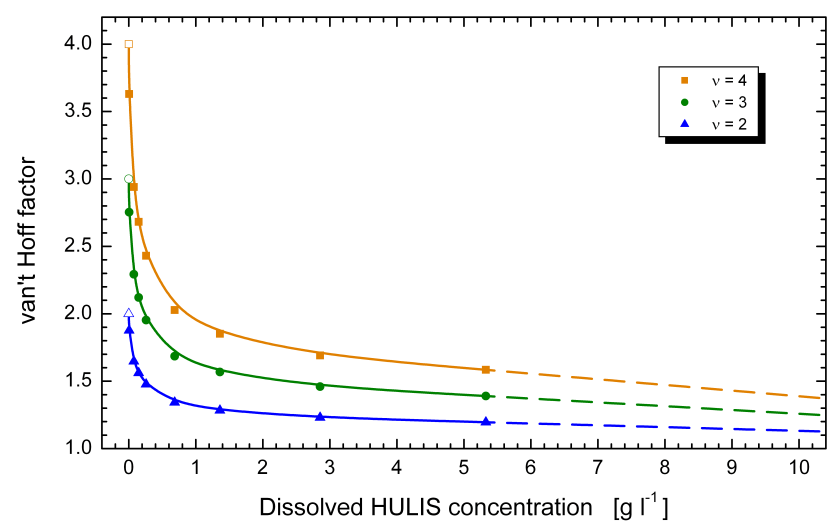

Fig. 5. Concentration dependence of the van't Hoff factor for pure HULIS solution for stoichiometric dissociation numbers of 2, 3 and 4.

dissolved (stoichiometric dissociation number). Considering that HULIS contain up to several (e.g., 1, 2 or 3) carboxyl groups per molecule (Tagliavini et al., 2005; Decesari et al., 2006), the van't Hoff factor equals $v$, which is 2,3 or 4 , respectively in their infinitely diluted solutions. The factors did decrease substantially and monotonically (corresponding to the change in the dissociation degree) with the concentration as shown in Fig. 5. This dependence was very remarkable in the beginning but became weak for rather concentrated solutions. The van't Hoff factors reached 1.13, 1.26, and 1.38, respectively at a concentration of approximately $10 \mathrm{gl}^{-1}$. Hence, for concentrated solutions, their magnitude is significantly smaller than the stoichiometric dissociation number but the variability is not large. This can be important for one of the atmospherically relevant cases, for growing cloud condensation nuclei. van't Hoff factors can be computed with existing thermodynamical models for inorganic salts or simple organic compounds (Raymond and Pandis, 2002) but modelling aggregate organic compounds-water systems, or complex organic compounds-inorganic salts-water systems is a rather challenging task. van't Hoff factors can be determined experimentally from water activity (Varga et al., 2007) but these measurements are sparse. For this reason, the van't Hoff factors for organics and their dependency on solution concentration are usually unknown, and in many studies (e.g., Facchini et al., 1999; Gysel et al., 2004; Henning et al., 2005; Svenningsson et al., 2006; Asa-Awuku et al., 2007), the missing data were approximated by constants of the stoichiometric dissociation number $i=v$ (assuming complete dissociation), or they were set equal to $i=1$ (if the organic compound was not expected to dissociate). The former approach could lead to substantial underestimation of the critical super-saturation, while the latter case could oversimplify the real situation (Kiss et al., 2005; Varga et al., 2007). The van't Hoff factor is directly related to the solution $\mathrm{pH}$, which depends on the acid dissociation constant of 
the carboxyl groups present in the HULIS molecules. To our knowledge, no experimentally measured van't Hoff factors for HULIS were presented earlier. Still, our results can be compared to some indirect conclusions that arose from empirical parameterization. It was observed, for instance, that a van't Hoff factor of approximately 1.3 for standard reference humic samples explained well the measured activation diameters in laboratory cloud condensation nuclei experiments (Dinar et al., 2006).

\section{Conclusions}

In the vast majority of studies, the properties of HULIS resemble those of aquatic and terrestrial fulvic and humic substances. The main differences that were presented and proved here include smaller molecular mass and smaller aromatic carbon abundance. The differences are most likely caused by different formation mechanisms. The isolation of HULIS from different source types (as primary and secondary ones) should, therefore, be achieved, and the fractions should be studied separately. At the same time, HULIS are regarded as inherently composite materials for which uniform behaviour and properties cannot always be expected. Spontaneous change in the aggregation and conformational states can take place under even slightly changing solution conditions, which can cause a part of the differences. The main external factors can include solution $\mathrm{pH}$, ionic strength, the presence of polyvalent metal ions and of dissociated cationic organic compounds, and therefore, explicit studies on the interactions between pure HULIS and other watersoluble aerosol constituents are also very desirable to assess the role of HULIS in real atmospheric aerosol particles. Some of the differences observed may well be the results of the diverse experimental methods and approaches applied. As far as the different classes of constituents within HULIS are concerned, two subsets were already observed in a previous study on the surface tension properties of pure HULIS solutions (Salma et al., 2006). The subsets of interest exhibited very large surface activity. Organo-sulphates, which were recently detected in $\mathrm{PM}_{2.5}$-sized secondary organic aerosol particles (Surrat et al., 2007), could be a possible candidate for one of the subsets. Further investigations are also definitely required in this topic.

It should be noted that characterisation of HULIS has been performed most frequently on samples separated from aqueous extracts since it is this chemical fraction that is of global importance due to its climatic and environmental impacts. Nevertheless, a subset of HULIS is not extractable in water, which indicates that there is a need for further investigations on the chemical entities of both water-soluble and water-insoluble material.
Acknowledgements. The financial support of the Hungarian Scientific Research Fund (contract K061193) is appreciated. The authors are grateful to W. Maenhaut of Ghent University, Belgium for the TOT analysis of the aerosol filters.

Edited by: T. Hoffmann

\section{References}

Asa-Awuku, A., Sullivan, A. P., Hennigan, C. J., Weber, R. J., and Nenes, A.: Investigation of molar volume and surfactant characteristics of water-soluble organic compounds in biomass burning aerosol, Atmos. Chem. Phys., 8, 799-812, 2008, http://www.atmos-chem-phys.net/8/799/2008/.

Baltensperger, U., Kalberer, M., Dommen, J., Paulsen, D., Alfarra, M.R., Coe, H., Fisseha, R., Gascho, A., Gysel, M., Nyeki, S., Sax, M., Steinbacher, M., Prevot, A. S. H., Sjögren, S., Weingartner, E., and Zenobi, R.: Secondary organic aerosols from anthropogenic and biogenic precursors, Faraday Discuss., 130, 265-278, 2005.

Birch, M. E. and Cary, R. A.: Elemental carbon-based method for monitoring occupational exposures to particulate diesel exhaust, Aerosol Sci. Technol., 25, 221-241, 1996.

Brown, T. L. and Rice, J. A.: Effect of experimental parameters on the ESI FT-ICR mass spectrum of fulvic acid, Anal. Chem., 72, 384-390, 2000.

Cappiello, A., De Simoni, E., Fiorucci, C., Mangani, F., Palma, P., Trufelli, H., Decesari, S., Facchini, M. C., and Fuzzi, S.: Molecular characterization of water-soluble organic compounds in fogwater by ESIMS/MS, Environ. Sci. Technol., 37, 1229-1240, 2003.

Chin, Y. P., Alken, G., and O'Loughlin, E.: Molecular weight, polydispersity, and spectroscopic properties of aquatic humic substances, Environ. Sci. Technol., 28, 1853-1858, 1994.

Decesari, S., Facchini, M. C., Fuzzi, S., and Tagliavini, E.: Characterization of water-soluble organic compounds in atmospheric aerosol: a new approach, J. Geophys. Res., D105, 1481-1489, 2000.

Decesari, S., Facchini, M.C., Matta, E., Lettini, F., Mircea, M., Fuzzi, S., Tagliavini, E., and Putaud, J.-C.: Chemical features and seasonal variation of fine aerosol water-soluble organic compounds in the Po Valley, Italy, Atmos. Environ., 35, 3691-3699, 2001.

Decesari, S., Facchini, M. C., Matta, E., Mircea, M., Fuzzi, S., Chughtai, A. R., and Smith, D. M.: Water soluble organic compounds formed by oxidation of soot, Atmos. Environ., 36, 18271832, 2002.

Decesari, S., Fuzzi, S., Facchini, M. C., Mircea, M., Emblico, L., Cavalli, F., Maenhaut, W., Chi, X., Schkolnik, G., Falkovich, A., Rudich, Y., Claeys, M., Pashynska, V., Vas, G., Kourtchev, I., Vermeylen, R., Hoffer, A., Andreae, M. O., Tagliavini, E., Moretti, F., and Artaxo, P.: Characterization of the organic composition of aerosols from Rondônia, Brazil, during the LBASMOCC 2002 experiment and its representation through model compounds, Atmos. Chem. Phys., 6, 375-402, 2006, http://www.atmos-chem-phys.net/6/375/2006/.

Dinar, E., Taraniuk, I., Graber, E. R., Katsman, S., Moise, T., Anttila, T., Mentel, T. F., and Rudich, Y.: Cloud condensation nu- 
clei properties of model and atmospheric HULIS, Atmos. Chem. Phys., 6, 2465-2482, 2006,

http://www.atmos-chem-phys.net/6/2465/2006/.

Dinar, E., Taraniuk, I., Graber, E. R., Anttila, T., Mentel, T. F., and Rudich, Y.: Hygroscopic growth of atmospheric and model humic-like substances, J. Geophys. Res., 112, D05211, doi:10.1029/2006JD007442, 2007.

Dinar, E., Riziq, A. A., Spindler, C., Erlick, C., Kiss, G., and Rudich, Y.: The complex refractive index of atmospheric and model humic-like substances (HULIS) retrieved by a cavity ring down aerosol spectrometer (CRD-AS), Faraday Discuss., 137, 279-295, 2008.

Facchini, M. C., Mircea, M., Fuzzi, S., and Charlson, R. J.: Cloud albedo enhancement by surface-active organic solutes in growing droplets, Nature, 401, 257-259, 1999.

Facchini, M. C., Decesari, S., Mircea, M., Fuzzi, S., and Loglio, G.: Surface tension of atmospheric wet aerosol and cloud/fog droplets in relation to their organic carbon content and chemical composition, Atmos. Environ., 34, 4853-4857, 2000.

Fuzzi, S., Decesari, S., Facchini, M. C., Matta, E., Mircea, M., and Tagliavini, E.: A simplified model of the water soluble organic component of atmospheric aerosol, Geophys. Res. Lett., 20, 4079-4082, 2001.

Fuzzi, S., Andreae, M. O., Huebert, B. J., Kulmala, M., Bond, T. C., Boy, M., Doherty, S. J., Guenther, A., Kanakidou, M., Kawamura, K., Kerminen, V.-M., Lohmann, U., Russell, L. M., and Pöschl, U.: Critical assessment of the current state of scientific knowledge, terminology, and research needs concerning the role of organic aerosols in the atmosphere, climate, and global change, Atmos. Chem. Phys., 6, 2017-2038, 2006,

http://www.atmos-chem-phys.net/6/2017/2006/.

Gelencsér, A., Sallai, M., Krivácsy, Z., Kiss, G., and Mészáros, E.: Voltammetric evidence for the presence of humic-like substances in fog water, Atmos. Res., 54, 157-165, 2000.

Gelencsér, A.: Carbonaceous Aerosol, Springer, Dordrecht, 2004.

Graber, E. R. and Rudich, Y.: Atmospheric HULIS: how humic-like are they? A comprehensive and critical review, Atmos. Chem. Phys., 5, 9801-9860, 2006,

http://www.atmos-chem-phys.net/5/9801/2006/.

Graham, B., Mayol-Bracero, O. L., Guyon, P., Roberts, G. C., Decesari, S., Facchini, M. C., Artaxo, P., Maenhaut, W., Köll, P., and Andreae, M. O.: Water-soluble organic compounds in biomass burning aerosol over Amazonia, 1. Characterization by NMR and GC-MS, J. Geophys. Res., 107(D20), 8047, doi:10.1029/2001JD000336, 2002.

Gysel, M., Weingartner, E., Nyeki, S., Paulsen, D., Baltensperger, U., Galambos, I., and Kiss, G.: Hygroscopic properties of water-soluble matter and humic-like organics in atmospheric fine aerosol, Atmos. Chem. Phys., 4, 35-50, 2004, http://www.atmos-chem-phys.net/4/35/2004/.

Havers, N., Burba, P., Lambert, J., and Klockow, D.: Spectroscopic characterisation of humic-like substances in airborne particulate matter, J. Atmos. Chem., 29, 45-54, 1998.

Hantz, P., Partridge, J., Láng, G., Horvát, S., and Ujvári, M.: Ionselective membranes involved in pattern-forming processes, J. Phys. Chem., B108, 18135-18139, 2004.

Henning, S., Rosenørn, T., D’ Anna, B., Gola, A. A., Svenningsson, B., and Bilde, M.: Cloud droplet activation and surface tension of mixtures of slightly soluble organics and inorganic salt, Atmos.
Chem. Phys., 5, 575-582, 2005,

http://www.atmos-chem-phys.net/5/575/2005/.

Kalberer, M., Paulsen, D., Sax, M., Steinbacher, M., Dommen, J., Prevot, A. S. H., Fisseha, R., Weingartner, E., Frankevich, V., Zenobi, R., and Baltensperger, U.: Identification of polymers as major components of atmospheric organic aerosols, Science, 303, 1659-1662, 2004.

Kiss, G., Varga, B., Galambos, I., and Ganszky, I.: Characterization of water-soluble organic matter isolated from atmospheric fine aerosol, J. Geophys. Res., 107(D21), 8339, doi:10.1029/2001JD000603, 2002.

Kiss, G., Tombácz, E., Varga, B., Alsberg, T., and Persson, L.: Estimation of the average molecular weight of humic-like substances isolated from fine atmospheric aerosol, Atmos. Environ., 37, 3783-3794, 2003.

Kiss, G., Tombácz, E., and Hansson, H.-C.: Surface tension effects of humic-like substances in the aqueous extract of troposphere fine aerosol, J. Atmos. Chem., 50, 279-294, doi:10.1007/s10874-005-5079-5, 2005.

Koehler, K. A., Kreidenweis, S. M., DeMott, P. J., Prenni, A. J., Carrico, C. M., Ervens, B., and Feingold, G.: Water activity and activation diameters from hygroscopicity data - Part II: Application to organic species, Atmos. Chem. Phys., 6, 795-809, 2006, http://www.atmos-chem-phys.net/6/795/2006/.

Krivácsy, Z., Kiss, G., Varga, B., Galambos, I., Sárvári, Z., Gelencsér, A., Molnár, A., Fuzzi, S., Facchini, M. C., Zappoli, S., Andracchio, A., Alsberg, T., Hansson, H.-C., and Persson, L.: Study of humic-like substances in fog and interstitial aerosol by size-exclusion chromatography and capillary electrophoresis, Atmos. Environ., 34, 4273-4281, 2000.

Kujawinski, E. B., Hatcher, P. G., and Freitas, M. A.: High resolution Fourier transform ion cyclotron resonance mass spectrometry of humic and fulvic acids: Improvements and comparisons, Anal. Chem., 74, 413-419, 2002.

Láng, G., Ujvári, M., and Inzelt, G.: Possible origin of the deviation from the expected impedance response of polymer film electrodes, Electrochim. Acta, 46, 4159-4175, 2001.

Leenheer, J. A., Rostad, C. E., Gates, P. M., Furlong, E. T., and Ferrer, I.: Molecular resolution and fragmentation of fulvic acid by electrospray ionization/multistage tandem mass spectrometry, Anal. Chem., 73, 1461-1471, 2001.

Limbeck, A., Kulmala, M., and Puxbaum, H.: Secondary organic aerosol formation in the atmosphere via heterogeneous reaction of gaseous isoprene on acidic particles, Geophys. Res. Lett., 30(19), 1996, doi:10.1029/2003GL017738, 2003.

Limbeck, A., Handler, M., Neuberger, B., Klatzer, B., and Puxbaum, H.: Carbon-specific analysis of humic-like substances in atmospheric aerosol and precipitation samples, Anal. Chem., 77, 7288-7293, 2005.

Mayol-Bracero, O. L., Guyon, P., Graham, B., Roberts, G., Andreae, M. O., Decesari, S., Facchini, M. C., Fuzzi, S., and Artaxo, P.: Water-soluble organic compounds in biomass burning aerosols over Amazonia, 2. Apportionment of the chemical composition and importance of the polyacidic fraction, J. Geophys. Res., 107(D20), 8091, doi:10.1029/2001JD000522, 2002.

Mazurek, M. A., Masonjones, M. C., Masonjones, H. D., Salmon, L. G., Cass, G. R., Hallock, K. A., and Leach, M.: Visibilityreducing organic aerosols in the vicinity of Grand Canyon National Park: properties observed by high resolution gas chro- 
matography, J. Geophys. Res., 102, 3779-3793, 1997.

McFiggans, G., Artaxo, P., Baltensperger, U., Coe, H., Facchini, M.C., Feingold, G., Fuzzi, S., Gysel, M., Laaksonen, A., Lohmann, U., Mentel, T. F., Murphy, D. M., O’Dowd, C.D., Snider, J. R., and Weingartner, E.: The effect of physical and chemical aerosol properties on warm cloud droplet activation, Atmos. Chem. Phys., 6, 2593-2649, 2006,

http://www.atmos-chem-phys.net/6/2593/2006/.

Peuravuori, J. and Pihlaja, K.: Molecular size distribution and spectroscopic properties of aquatic humic substances, Anal. Chim. Acta, 337, 133-149, 1997.

Puxbaum, H., Rendl, J., Allabashi, R., Otter, L., and Scholes M. C.: Mass balance of atmospheric aerosol in a South-African subtropical savanna (Nylsvley, May 1997), J. Geophys. Res., 105, 20697-20706, 2000.

Puxbaum, H. and Tenze-Kunit, M.: Size distribution and seasonal variation of atmospheric cellulose, Atmos. Environ., 37, 36933699, 2003.

Raymond, T. R. and Pandis, S. N.: Cloud activation of single-component organic aerosol particles, J. Geophys. Res., 107(D24), 4787, doi:10.1029/2002JD002159, 2002.

Rogge, W. F., Mazurek, M. A., Hildemann, L. M., and Cass, G. R.: Quantification of urban organic aerosols at a molecular level: Identification, abundance and seasonal variation, Atmos. Environ., 27A, 1309-1330, 1993.

Schauer, J. J., Mader, B. T., DeMinter, J. T., Heidemann, G., Bae, M. S., Seinfeld, J. H., Flagan, R. C., Cary, R. A., Smith, D., Huebert, B. J., Bertram, T., Howell, S., Quinn, P., Bates, T., Turpin, B., Lim, H. J., Yu, J., and Yang, H.: ACE-Asia Intercomparison of a thermal optical method for the determination of particlephase organic and elemental carbon, Environ. Sci. Technol., 37, 993-1001, 2003.

Salma, I., Chi, X., and Maenhaut, W.: Elemental and organic carbon in urban canyon and background environments in Budapest, Hungary, Atmos. Environ., 38, 27-36, 2004.

Salma, I., Ocskay, R., Varga, I., and Maenhaut, W.: Surface tension of atmospheric humic-like substances in connection with relaxation, dilution, and solution pH, J. Geophys. Res., 111, D23205, doi:10.1029/2005JD007015, 2006.

Salma, I. Ocskay, R., Chi, X., and Maenhaut, W.: Sampling artefacts, concentrations and chemical composition of fine watersoluble organic carbon and humic-like substances in a continental urban atmospheric environment, Atmos. Environ., 41, 41064118, 2007.

Samburova, V., Zenobi, R., and Kalberer, M.: Characterization of high molecular weight compounds in urban atmospheric particles, Atmos. Chem. Phys., 5, 2163-2170, 2005,

http://www.atmos-chem-phys.net/5/2163/2005/.

Samburova, V., Didenko, T., Kunenkov, E., Emmenegger, Ch., Zenobi, R., and Kalberer, M.: Functional group analysis of highmolecular weight compounds in the water-soluble fraction of organic aerosols, Atmos. Environ., 41, 4703-4710, 2007.

Saxena, P. and Hildemann, L. M.: Water-soluble organics in atmospheric particles: A critical review of the literature and application of thermodynamics to identify candidate compounds, J. Atmos. Chem., 24, 57-109, 1996.

Schäfer, A. I., Mauch, R., Waite, T. D., and Fane, A. G.: Charge effects in the fractionation of natural organics using ultrafiltration, Environ. Sci. Technol., 36, 2572-2580, 2002.
Sullivan, A. P. and Weber, R. J.: Chemical characterization of the ambient organic aerosol soluble in water: 1 . Isolation of hydrophobic and hydrophilic fractions with a XAD-8 resin, J. Geophys. Res., 111, D05314, doi:10.1029/2005JD006485, 2006a.

Sullivan, A. P. and Weber, R. J.: Chemical characterization of the ambient organic aerosol soluble in water: 2. Isolation of acid, neutral, and basic fractions by modified sizeexclusion chromatography, J. Geophys. Res., 111, D05315, doi:10.1029/2005JD006486, 2006b.

Surratt, J. D., Kroll, J. H., Kleindienst, T. E., Edney, E. O., Claeys, M., Sorooshian, A., Ng, N. L., Offenberg, J. H., Lewandowski, M., Jaoui, M., and Seinfeld, J. H.: Evidence for organosulfates in secondary organic aerosol, Environ. Sci. Techn., 42, 517-527, doi:10.1021/es062081q, 2007.

Svenningsson, B., Rissler, J., Swietlicki, E., Mircea, M., Bilde, M., Facchini,M. C., Decesari, S., Fuzzi, S., Zhou, J., Mønster, J., and Rosenørn, T.: Hygroscopic growth and critical supersaturations for mixed aerosol particles of inorganic and organic compounds of atmospheric relevance, Atmos. Chem. Phys., 6, 1937-1952, 2006, http://www.atmos-chem-phys.net/6/1937/2006/.

Szidat, S., Jenk, T. M., Gäggeler, H. W., Synal, H.-A., Fisseha, R., Baltensperger, U., Kalberer, M., Samburova, V., Reimann, S., and Hajdas, I.: Radiocarbon $\left({ }^{14} \mathrm{C}\right)$-deduced biogenic and anthropogenic contributions to organic carbon (OC) of urban aerosols from Zürich, Switzerland, Atmos. Environ., 38, 40354044, 2004.

Tabazadeh, A.: Organic aggregate formation in aerosols and its impact on the physicochemical properties of atmospheric particles, Atmos. Environ., 39, 5472-5480, 2005.

Tagliavini, E., Moretti, F., Decesari, S., Facchini, M. C., Fuzzi, S., and Maenhaut, W.: Functional group analysis by $\mathrm{H}$ $\mathrm{NMR} /$ chemical derivatization for the characterization of organic aerosol from the SMOCC field campaign, Atmos. Chem. Phys., 6, 1003-1019, 2005, http://www.atmos-chem-phys.net/6/1003/2005/.

Taraniuk, I., Graber, E. R., Kostinski, A., and Rudich, Y.: Surface tension and diffusion coefficients of atmospheric and model humic like species (HULIS), Geophys. Res. Lett., 34, L16807, doi:16810.11029/12007GL029576, 2007.

Tombácz, E.: Colloidal properties of humic acids and spontaneous change of their colloidal state under variable solution conditions, Soil Sci., 164, 814-824, 1999.

Traina, S. J., Novak, J., and Smeck, N. E.: An ultraviolet absorbance method of estimating the percent aromatic carbon content of humic acids, J. Environ. Qual., 19, 151-153, 1990.

Varga, B., Kiss, G., Ganszky, I., Gelencsér, A., and Krivácsy, Z.: Isolation of water soluble organic matter from atmospheric aerosol, Talanta, 55, 561-572, 2001.

Varga, Z., Kiss, G., and Hansson, H.-C.: Modelling the cloud condensation nucleus activity of organic acids on the basis of surface tension and osmolality measurements, Atmos. Chem. Phys., 7, 4601-4611, 2007,

http://www.atmos-chem-phys.net/7/4601/2007/.

Wex, H., Hennig, T., Salma, I., Ocskay, R., Kiselev, A., Henning, S., Massling, A., Wiedensohler, A., and Stratmann, F.: Hygroscopic growth and measured and modeled critical supersaturations of an atmospheric HULIS sample, Geophys. Res. Lett., 34, L02818, doi:10.1029/2006GL028260, 2007. 
Zappoli, S., Andracchio, A., Fuzzi, S., Facchini, M. C., Gelencsér, A., Kiss, G., Krivácsy, Z., Molnár, A., Mészáros, E., Hansson, H.-C., and Rosman, K.: Inorganic, organic and macromolecular components of fine aerosol in different areas of Europe in relation to their water solubility, Atmos. Environ., 33, 2733-2743, 1999.
Ziese, M., Wex, H., Nilsson, E., Salma, I., Ocskay, R., Hennig, T., Massling, A., and Stratmann, F.: Hygroscopic growth and activation of HULIS particles: experimental data and a new iterative parameterization scheme for complex aerosol particles, Atmos. Chem. Phys., 8, 1855-1866, 2008,

http://www.atmos-chem-phys.net/8/1855/2008/. 